REVISTA

MEXICANA DE

ECONOMÍA Y

FINANZAS

REMEF

(THE MEXICAN JOURNAL OF

ECONOMICS AND FINANCE)
Revista Mexicana de Economía y Finanzas, Nueva Época

Volumen 16 Número 4, Octubre - Diciembre 2021, pp. 1-24, e610

DOI: https://doi.org/10.21919/remef.v16i4.610

(First reception: April 13, 2020, Last reception: December 5, 2020, Accepted: January 26, 2021, Published: March 10, 2021)

\title{
The Entrepreneurial Social Discount Rate: Risk Premium and Loss Aversion in New Ventures
}

\author{
David Ceballos Hornero ${ }^{1}$ - Universitat de Barcelona, España \\ Samuel Mongrut Montalván² - Tecnológico de Monterrey, EGADE Business \\ School, México \& Universidad del Pacifico, Perú
}

We derive a mathematical extension of the social discount rate (SDR) in such a way that we can valuate intergenerational startups financed with personal and government funds at the aggregate level. The results imply that the precise determination of the SDR can change the financial priority of investment. Therefore, we recommend government officials to include factors of economic growth (wealth effect), intergenerational prevention (precautionary effect), loss aversion, and the specific risk of the business in the valuation of new ventures and in the estimation of the social discount rate to be more representative of the social utility. Our contribution lies in including a risk premium from the firm's average non-systematic risk and the loss aversion of a representative investor in estimating the SDR.

JEL Classification: D15, G41, L26.

Keywords: Social discount rate, non-systematic risk, loss aversion, entrepreneurship.

\section{La tasa de descuento social empresarial: prima de riesgo y aversión a las pérdidas en nuevas empresas}

En esta investigación se deriva matemáticamente una extensión de la tasa de descuento social para valorar nuevas empresas intergeneracionales financiadas con capital personal y con fondos gubernamentales a nivel agregado. Los resultados implican que la determinación precisa de la tasa social de descuento cambia la prioridad financiera al invertir. Por tanto, recomendamos a los oficiales del gobierno que incluyan factores de crecimiento económico (efecto riqueza), prevención intergeneracional (efecto de precaución), aversión a las pérdidas y el riesgo específico de los negocios en la valoración de nuevos emprendimientos y en la determinación de la tasa de descuento social para ser más representativa de la utilidad social. Nuestra contribución radica en incluir una prima promedio por riesgo no sistemático de la empresa y la aversión a la pérdida de un inversionista representativo en la estimación de la tasa de descuento social.

Clasificación JEL: D15, G41, L26.

Palabras clave: Tasa de descuento social, riesgo no sistemático, aversión al riesgo de pérdida, emprendimiento.

${ }^{1}$ Corresponding author: Av. Diagonal 690. 08034 Barcelona (Spain). ceballos@ub.edu ORCID: https://orcid.org/00000002-0781-7115.

2 ORCID: https://orcid.org/0000-0003-2081-5576.

* No source of funding for research development 


\section{Introduction}

The financial valuation of an investment project depends on the discount rate, and additional behavioural factors that are increasingly present in the economic and financial literature (see, e.g., Zhuang et al. 2009; Arrow et al. 2014; Mongrut and Juarez 2020). The debate on the discount rate reflects the lack of practical proposals that lead to its determination because those that exist are mainly theoretical, although there are some integrated proposals like Ge et al. (2005).

The financial decision process is based on the maximization of the market value of assets that means the maximum present value of future benefits. In this way, the net present value (NPV) of a project is optimal if cash flows are positive, and the weighted average cost of capital is at a minimum. If the NPV is positive, then the return of the project is higher than the cost of funds, and the project is financially desirable (Rodriguez, 2019).

However, from a financial point of view, the main source of funding for new ventures is personal savings (Frid, 2014). This situation poses two important questions: what is the proper return that, on average, entrepreneurs' should get from investing their personal funds in their new ventures? What factors do they need to consider? The usual answer to these questions lies in the realm of entrepreneurial investment decisions, but they are also particularly important questions to answer from the perspective of public financing because government funds are critical to new ventures. Hence, answering these questions requires the perspective of the social discount rate (SDR). Society can use the SDR to give relative weight to social consumption or income accruing at different points in time (Price, 1988).

There are two important differences between the entrepreneurial perspective and the SDR perspective: First, the SDR perspective supposes a global and social vision, while the entrepreneurial perspective focuses on the individual analysis of a new venture (Armitage, 2014). This difference means that the SDR perspective only considers the systematic risk or the risk that you cannot diversify because it embodies an investment portfolio. However, new ventures carry a great deal of non-systematic or specific risk, and therefore entrepreneurs care about the investment's specific risk as well.

Second, the public financing perspective has usually assumed no cognitive bias because society chooses and consumes neutrally. However, entrepreneurs have cognitive biases due to their psychological perception of their own knowledge and skills that may lead to moderate or excessive overconfidence (Nofsinger, 2017; Mongrut and Juarez, 2018). This new perspective is compatible with the prospect theory and the presence of loss aversion in the valuation of new ventures. Furthermore, these biases do not vanish once we consider an aggregate set of entrepreneurs in a particular economy.

The role of the government in promoting entrepreneurship is a key element of the economy. Rathje and Katila (2018) studied over 33,000 US patents from 1982 to 2012 that resulted from public-private $R \& D$ collaborations and concluded that these alliances provide many advantages. They found that these collaborations produced more disruptive and impactful innovations than private firms acting on their own because the government could provide access to national 
infrastructure facilities and information. Moreover, it could serve as the lead market for new technologies.

Therefore, government officials in charge of promoting entrepreneurship should improve the way in which they select and sponsor startups. This is even more important because most new ventures start operations without business angels or venture capitalists. Further, Cumming et al. (2018) identify the possible negative externalities and spillovers across different sources of financing. They show that the central factor that impedes complementarities across different forms of entrepreneurial financing is the excessive ownership dilution of entrepreneurs in favor of business angels and venture capitalists.

In this context, for the first time in the public financing literature we identify the firm's specific risk and the entrepreneur's loss aversion coefficient as two important factors that government officials should consider when estimating the SDR. We argue that this amendment to the SDR is useful to governments by helping them choose the best investments for the well-being of society. Therefore, we start our analysis with Gollier's development of the SDR (2011) and then we expand the formula by adding our two factors.

Our contribution to the literature lies in deriving expressions of the SDR that involve the entrepreneurs' cognitive bias (loss aversion) and the firms' specific risk. We call this expression the entrepreneurial social discount rate (ESDR). An application of the model can be useful for public policy and public agencies in charge of promoting entrepreneurship when they finance programs with a long-term horizon.

In the next section, we conduct a literature review about the concept of the SDR, while in the third and fourth sections we discuss the risk premium due to the new ventures' specific risk and the entrepreneurs' loss-risk aversion. In the fifth section we derive the ESDR that involves both factors, and in the sixth section we present a numerical application of the formula. The last section concludes this study.

\section{Literature Review}

The SDR is the rate that society uses to put a present value on the cost and benefits of investments in social projects. These investments are characterised by their long term (intergenerational) and their public and global or aggregate perspective (not individual risk).

Recently, studies have applied the estimation of the SDR in several ways. They have used it to pull future benefits and costs of climate change back to the present (Nordhaus, 2007) or to evaluate health-care programs (Drummond et al, 2005). Nevertheless, to the best of our knowledge there has not been any attempt to involve new venture's specific risk nor behavioural aspects in its estimation.

In the classical theory without behavioural effects, studies use a model of intertemporal consumption to obtain the SDR. In other words, they first obtain the consumption discount rate and then determine the social values of the different components. Gollier (2011) developed the determination of the consumption discount rate by using the classical Ramsey's formula with four elements: 
a) An intertemporal welfare function (V): it is equal to the utility function of present consumption $\left(\mathrm{u}\left(\mathrm{c}_{0}\right)\right)$ plus the present value of the expected utility of future consumption $\left.\left(E\left[c_{t}\right)\right]\right)$ by using a discount rate that represents pure preference $(\delta)$ :

$$
V=u\left(c_{0}\right)+e^{-\delta t} E\left[\left(c_{t}\right)\right]
$$

b) A Pareto efficient for consumption allocation that is the sum of the welfare of all individuals in the society:

$$
W=\sum_{i}\left(\lambda_{i} V_{i}\right)
$$

c) A constant relative risk aversion $(\gamma)$ utility function:

$$
u(c)=c^{1-\gamma} / 1-\gamma
$$

d) A growth rate of consumption normally distributed with mean $\left(\mu_{g}\right)$ and variance $\sigma_{g}^{2}$.

The first order condition on the maximization of this social welfare function results in the consumption social discount rate $(\rho)$ that is equal to:

The annual continuous time is:

$$
\rho=\delta+\gamma \mu_{g}-0.5 \gamma^{2} \sigma_{g}^{2}
$$

The annual discrete time is:

$$
r=e^{\rho}-1
$$

Where equation (4) is known as the "extended Ramsey rule".

From a SDR perspective, the intergenerational rate of pure preference is equal to zero because there is no preference for any generation. This equation is also compatible with a timedeclining discount rate because in the very long term with an uncertain consumption growth rate and a concave utility function, the instantaneous growth rate of expected consumption tends to its minimum Gollier (2008).

If we consider the case of intertemporal consumption choice in the scenario that the consumer has to consume all income over their lifetime, then the growth rate of consumption can be substituted with the growth rate of the economy. Then, according to the framework presented by Ramsey (1928) and its extension by Gollier $(2011,2013)$, the SDR has three identifiable components:

a) The discount rate of pure preference (?): This rate of impatience can be considered normatively positive to justify the time preference, or ethically zero when it is applied to different human generations for an equalitarian treatment of the utility of each generation. 
b) The wealth effect: In general, the growth of an economy is positive that justifies a positive discount rate. Hence, every marginal investment in the present has to compensate for the smaller marginal utility of consumption in the future or the increase in the intertemporal inequity that the investment generates.

c) The precautionary effect: It occurs when the future is more uncertain because people save more since it is rational (whenever you prefer stable consumption) to save in the present if you think your income will be smaller in the future (Gollier, 2011).

\section{The First Amendment: Risk Premium}

From an efficient social perspective, we assume that non-systematic risks are zero because diversification is optimal. But, new ventures or start-ups cannot diversify their specific or nonsystematic risk.

In this context, Petrakis (2004, pg. 96) concludes that

...the risk premium of the economic agent of neoclassical theory is nothing more than the entrepreneurship premium from entrepreneurial theories. If, though, this is absolutely and readily acceptable, then the measurement of the level of (non-systematic) risk can allow for a satisfactory 'revelation' of the level of entrepreneurship in economic activity.

In fact, Petrakis (2004) finds a positive correlation between non-systematic risk and the growth rate of consumption of about 25\%. Furthermore, Book (1999) recommend using a correlation between $20 \%$ and $30 \%$ whenever a functional correlation does not exist. Hence, we can rewrite equation (4) as:

$$
\rho^{*}=\delta+\gamma(1+0.25 N S R) \mu_{g}-0.5 \gamma^{2} \sigma_{g}^{2}
$$

Where:

$\rho$ is the annual continuous rate for valuation,

$\delta$ is the pure preference for liquidity,

$\gamma$ is the constant relative risk aversion,

NSR is the non-systematic risk of the new venture,

$\mu_{g}$ is the mean of the annual growth rate of consumption, and

$\sigma_{g}^{2}$ is the variance of the annual growth rate of consumption.

Equation (6) adds a risk premium (RP) that is equal to:

$$
R P=(0.25) \gamma \mu_{g} N S R
$$

We can understand this RP in the following way:

$$
R P=\left(\beta_{N S R, g}\right)\left(\mu_{g}\right)
$$


In this case the RP represents the sensitivity of the "beta" of the new venture's specific risk with respect to the growth rate if consumption equals the mean annual growth rate of consumption. We can rewrite the previous expression in the following way:

$$
R P=\frac{\sigma_{S R}}{\sigma_{g}}\left(\rho_{S R, g}\right)\left(\mu_{g}\right)=(0.25) \gamma \mu_{g} N S R
$$

Where the standard deviation of the new venture's specific risk $\left(\sigma_{S R}\right)$ is in fact the NSR, the correlation coefficient is equal to 0.25 , and the constant relative risk aversion is the inverse of the standard deviation of the annual growth rate of consumption $\left(\gamma=\frac{1}{\sigma_{g}}\right)$.

Leach and Melicher (2020) conclude that the reason that a higher interest rate exists on funding to new ventures is because the operational and financial risks of the business need to be included to indicate financial distress, where both risks are non-systematic. This is another way to justify the presence of the NSR in equation (6).

\section{Second Amendment: Prospect Theory}

Kahneman and Tversky (1979) introduced the prospect theory that states that human beings weight their losses more than their gains. Since their decision to invest in a new venture is subjective, cognitive bias and psychological traits play a role in the entrepreneurs' choices. The typical lossaversion coefficient is equal to 2 that means a utility of 1 in a gain is equivalent to a disutility between 1.5 to 2.5 times in a loss (Novemsky and Kahneman, 2005). We introduce the cognitive bias effect in equation (4) by using an alternative double approach: consumption and cash flows.

For consumption, we use a constant relative risk aversion (可) utility function with 2 periods ( 0 and $t$ ) that is defined by equation (3). In this case the utility function has two branches because it is asymmetric with respect to the increase or decrease in the future consumption in relation to the present consumption by the effect of loss aversion. With a coefficient of 2 , the loss aversion supposes the disutility of a loss is double the utility of the same absolute earning. This supposition means that we must discount a loss twice, or the difference between the future consumption and the present one when the future consumption is lower than the second one.

A.

$$
u(c)={ }^{c_{i t}-\gamma} / 1-\gamma
$$

when consumption increases because of the positive return on investments $c_{i t}>c_{i 0}$.

B. $\quad u(c)=\left(c_{i t}^{1-\gamma}-\left(c_{i t}-c_{i 0}\right)^{1-\gamma}\right) / 1-\gamma$

when consumption decreases because of the negative return on investments $c_{i t}<c_{i 0}$. 
Hence, the SDR has two branches. The first branch is when future consumption $\left(\mathrm{c}_{\mathrm{it}}\right)$ is higher or equal to present consumption $\left(\mathrm{c}_{\mathrm{i} 0}\right)$. In this case, the continuous discount rate is similar to the general case (equation 4):

$$
\rho=\delta+\gamma \mu_{g}-0.5 \gamma^{2} \sigma_{g}^{2}
$$

The second branch is when future consumption is lower than present consumption as reflected by a loss-aversion coefficient of 2 , suppose:

$$
\rho=\delta+2 \gamma \mu_{g}-\gamma^{2} \sigma_{g}^{2}
$$

Equations (9) and (10) are developed in section 5.

For cash flows: we can heuristically derive the adjusted discount rate because if the lossaversion coefficient is 2 , it means that the amount you could possibly win would need to be at least twice as large as the amount you could lose before you would accept the risk. This tendency reflects loss aversion, or the idea that losses generally have a much larger psychological impact than gains of the same size (Kahneman and Tversky, 1979). This means that the capitalization rate of losses must be higher than the capitalization rate of gains in order to equal utility, and this proportion is maintained in the discount rate. Mathematically, their value is equal at a moment $t$ :

$$
2 C F_{\text {positive }} e^{\rho t}=\operatorname{abs}\left(C F_{\text {negative }}\right) e^{\rho_{\text {lossaversion }} t}
$$

Where CF is the cash flows with the same absolute value (change sign) whether positive or negative, and $\rho$ is the continuous capitalization rate for positive cash flows $(\rho)$ and for negative cash flows $\left(\rho_{\text {lossaversion}}\right)$.

Then,

$$
\begin{aligned}
& e^{\left(\rho_{\text {lossaversion }}-\rho\right) t}=2 \\
& \rho_{\text {lossaversion }}-\rho=\log 2 / t \\
& \rho_{\text {lossaversion }}=\rho+\log 2 / t
\end{aligned}
$$

We assume this relation between rates (for gains and losses) is the same for the derivation of SDR. The discrete time annual equivalent rate is the following?:

$$
r=e^{\rho}-1 ; 1+r=e^{\rho} ; \log (1+r)=\rho
$$

3 In the appendix we show the relation between the returns with loss aversion and without loss aversion in continuous and discrete time. 


$$
\begin{aligned}
& \rho_{\text {lossaversion }}=\log \left(1+r_{\text {lossaversion }}\right)=\log (1+r)+\log 2 / t=\log (1+r)+\log 2^{1 / t}= \\
& \log \left[(1+r)\left(2^{1 / t}\right)\right] \\
& \log \left(1+r_{\text {lossaversion }}\right)=\log \left[(1+r)\left(2^{1 / t}\right)\right] ; 1+r_{\text {lossaversion }}=(1+r)\left(2^{1 / t}\right)(17) \\
& r_{\text {lossaversion }}=(1+r)\left(2^{1 / t}\right)-1
\end{aligned}
$$

Where:

$r_{t}$ is the discount rate for positive returns from liquidity in t periods, and

$r_{\text {lossaversiont }}$ is the discount rate for negative returns in period " $\mathrm{t}$ ".

Further, the discount rate of loss aversion (for losses) is dependent on time and is higher during the first period and then declines and converges with the discount rate for positive cash flows (earnings). According to Arrow et al. (2014), these discount rates in the long term converge with the minimum growth rate of the consumption. Given these results, we can rewrite equation (4) that does not change for gains and involves loss aversion in continuous time and discrete time:

A) Annual continuous time rate (for positive and negative returns, respectively):

$$
\begin{gathered}
\rho=\delta+\gamma \mu_{g}-0.5 \gamma^{2} \sigma_{g}^{2} \\
\rho_{\text {lossaversion }}=\delta+\gamma \mu_{g}-0.5 \gamma^{2} \sigma_{g}^{2}+\log 2 / t
\end{gathered}
$$

B) Annual discrete time rates (for positive and negative returns, respectively):

$$
\begin{gathered}
r=e^{\delta+\gamma \mu_{g}-0.5 \gamma^{2} \sigma_{g}^{2}}-1 \\
\left(r_{\text {lossaversion }}\right)_{t}=e^{\delta+\gamma \mu_{g}-0.5 \gamma^{2} \sigma_{g}^{2}} 2^{1 / t}-1
\end{gathered}
$$

\section{The Entrepreneurial Social Discount Rate}

In this section we derive the entrepreneurial social discount rate (ESDR) that we define as the rate of return to new ventures that society requires when entrepreneurs' use a mix of their funds and government funds. We derive the expressions using two approaches: cash flows and consumption. 


\section{The cash-flow approach:}

The derivation of the ESDR is heuristic in the sense that we add the risk premium and the loss aversion of the representative investor to Gollier's formula of SDR. The two branches of the annual ESDR in discrete time are the following:

$$
\begin{gathered}
r=e^{\delta+\gamma(1+0.25 N S R) \mu_{g}-0.5 \gamma^{2} \sigma_{g}^{2}}-1 \\
\left(r_{\text {lossaversion }}\right)_{t}=e^{\delta+\gamma(1+0.25 N S R) \mu_{g}-0.5 \gamma^{2} \sigma_{g}^{2}} 2^{1 / t}-1
\end{gathered}
$$

\section{The consumption approach:}

We follow the same intertemporal model of two periods as Gollier (2011) with an economy with $\mathrm{n}$ agents indexed by $i=1, \ldots, n$. Agent i consumes $c_{\mathrm{i} 0}$ on date 0 (present) and $c_{i t}$ on date $\mathrm{t}$ (in years). The annual growth rate of consumption of agent $i$ in this period is calculated by the formula:

$$
x_{i t}=\log \left(c_{i t} / c_{i 0}\right) /_{t}
$$

Additionally, we assume that agent $i$ cannot accumulate savings and therefore, all the returns of the savings in the first period are consumed in the second period. An agent has an initial income (w) equal to:

$$
\left(w_{i}\right)_{0}=c_{i 0}+s_{i 0}
$$

Where $s_{i 0}$ are the savings that in turn will produce an annual continuous return of ? ? next period. This return means:

$$
c_{i t}=\left(w_{i}\right)_{t}+s_{i 0} e^{\rho t}
$$

If $s_{i 0}<0$, then it means that the agent takes debt at the same rate as safe investments.

For simplicity, we consider $\mathrm{w}_{\mathrm{i} 0}=\mathrm{w}_{\mathrm{it}}$ that represents a constant income equal to $\mathrm{w}$ :

$$
c_{i t}=w+\left(w-c_{i 0}\right) e^{\rho t}=w\left(1+e^{\rho t}\right)-c_{i 0} e^{\rho t}
$$

Agents evaluate their intertemporal welfare $V_{i}$ by the discounted flow of the expected utility of their consumption with an increasing and concave utility function $u($ ) that has an annual continuous rate of pure preference for the present equal to $\delta$, according to equation (1):

$$
V_{i}=u\left(c_{i 0}\right)+e^{-\delta t} E\left[u\left(c_{i t}\right)\right]
$$

We assume that the utility function of the representative agent has a constant relative risk aversion $(\gamma)$ like: 


$$
u(c)=c^{1-\gamma} / 1-\gamma
$$

However, we introduce to the representative agent $i$ their aversion to the loss of their personal savings from investing in the new venture. However, the aggregation of personal savings is equivalent to government funds because a Pareto efficient allocation means that there is a representative agent in the economy. We assume a loss-aversion coefficient of 2 , like the most of practical cases (Novemsky and Kahneman, 2005). Then, the utility function has two branches:

$$
\begin{gathered}
u\left(c_{i 0}\right)=\left(c_{i 0}\right)^{1-\gamma} / 1-\gamma \\
u\left(c_{i t}\right)=u\left[f\left(c_{i t}\right)\right]=\left(c_{i t}+\min \left\{0,\left(c_{i t}-c_{i 0}\right)\right\}\right)^{1-\gamma} / 1-\gamma \\
\left(c_{i t}\right)=\left\{\begin{array}{c}
\left(c_{i t}\right)^{1-\gamma} / 1-\gamma, c_{i 0}<c_{i t} \\
\left(2 c_{i t}-c_{i 0}\right)^{1-\gamma} / 1-\gamma, c_{i 0} \geq c_{i t}
\end{array}\right.
\end{gathered}
$$

If the allocation of consumption across time and states of nature is Pareto efficient, then there is a vector of positive Pareto weights $\left(\lambda_{1}, \ldots, \lambda_{n}\right)$, so that this allocation maximizes the utilitarian social welfare $W=\sum_{i}\left(\lambda_{i} V_{i}\right)$ (34) that is subject to feasibility constraints.

Next, we plug equation (29) into the Pareto efficient condition for society (sum of all agents i):

$$
W=\sum_{i} \lambda_{i}\left(u\left(c_{i 0}\right)+e^{-\delta t} E\left[u\left(c_{i t}\right)\right]\right)
$$

If consumption increases, $c_{i t}>c_{i 0}$, then

$$
\begin{gathered}
W=\sum_{i} \lambda_{i}\left(u\left(c_{i 0}\right)+e^{-\delta t} E\left[u\left(c_{i t}\right)\right]\right)=\sum_{i} \lambda_{i}\left(u\left(c_{i 0}\right)+e^{-\delta t} E\left[u\left(\left(1+e^{\rho t}\right) w-c_{i 0} e^{\rho t}\right)\right]\right)= \\
\sum_{i} \lambda_{i}\left(\left(c_{i 0}\right)^{1-\gamma} / 1-\gamma+e^{-\delta t} E\left[\left(\left(1+e^{\rho t}\right) w-c_{i 0} e^{\rho t}\right)^{1-\gamma} / 1-\gamma\right]\right)
\end{gathered}
$$

This result means that the following necessary and sufficient conditions are satisfied:

$$
\lambda_{i} u^{\prime}\left(c_{i \tau}\right)=\lambda_{j} u^{\prime}\left(c_{1 \tau}\right), \text { for all } \mathrm{j}=1,2, \ldots \mathrm{i}, \ldots, \mathrm{n},
$$

because all agents are equal (represented by agent i).

Agent $i=1$ is hereafter identified as the representative agent in this economy. Then the best option is to maximize the social welfare function:

$$
\frac{\partial W}{\partial c}=0
$$




$$
\frac{\partial W}{\partial c}=\sum_{i} \lambda_{i}\left(\frac{\partial u\left(c_{i 0}\right)}{\partial c}-e^{(\rho-\delta) t} E\left[\frac{\partial u\left(c_{i t}\right)}{\partial c}\right]\right)=\quad \sum_{i} \lambda_{i}\left(u^{\prime}\left(c_{i 0}\right)-e^{(\rho-\delta) t} E\left[u^{\prime}\left(c_{i t}\right)\right]\right)=0
$$

In a context of efficient risk-sharing, this result means:

$$
\begin{gathered}
u^{\prime}\left(c_{i 0}\right)-e^{(\rho-\delta) t} E\left[u^{\prime}\left(c_{i t}\right)\right]=0 \\
e^{(\rho-\delta) t}=u^{\prime}\left(c_{i 0}\right) / E\left[u^{\prime}\left(c_{i t}\right)\right] \\
\log e^{\rho t}=\log \left(e^{\delta t} u^{\prime}\left(c_{i 0}\right) / E\left[u^{\prime}\left(c_{i t}\right)\right]\right)=\log e^{\delta t}-\log \left(E\left[u^{\prime}\left(c_{i t}\right)\right] / u^{\prime}\left(c_{i 0}\right)\right) \\
\rho t=\delta t-\log \left(E\left[u^{\prime}\left(c_{i t}\right)\right] / u^{\prime}\left(c_{i 0}\right)\right)
\end{gathered}
$$

We also assume that if the annual continuous growth rate of consumption $x_{i t}$ is normally distributed with mean $\mu_{g}$ and variance $\sigma_{g}^{2}$, then its statistical expected value can be approximated by $\mu_{g}-0.05 \sigma_{g}^{2}$ because the properties of the moment-generating function of a normal distribution $E\left(e^{x t}\right)=e^{\left(\mu+0.5 \sigma^{2}\right) t}$ where $\mathrm{x}$ is normally distributed

$$
\begin{gathered}
E\left[u^{\prime}\left(c_{i t}\right)\right]=\left(c_{i 0}\right)^{-\gamma} /\left(c_{i 0}\right)^{-\gamma} E\left[u^{\prime}\left(c_{i t}\right)\right]=\left(c_{i 0}\right)^{-\gamma} E\left[e^{\left(\log \left(c_{i 0}\right)^{-\gamma}\right)} e^{\log \left[u \prime\left(c_{i t}\right)\right]}\right]=\left(c_{i 0}\right)^{-\gamma} E\left[e^{-\gamma x_{i t} t}\right]= \\
\left(c_{i 0}\right)^{-\gamma} e^{\left(-\gamma\left(\mu_{g}-0.5 \gamma \sigma_{g}^{2}\right) t\right)}
\end{gathered}
$$

Because

$$
u^{\prime}(c)=\frac{\partial u(c)}{\partial c}=\frac{\partial\left(c^{1-\gamma} / 1-\gamma\right)}{\partial c}=(1-\gamma)^{c^{1-\gamma-1}} / 1-\gamma=c^{-\gamma}
$$

And

$$
x_{i t}=\log \left({ }^{c_{i t}} / c_{i 0}\right)
$$

And then equation (43) can be rewritten in continuous time as:

$$
\begin{aligned}
& \rho t=\delta t+\left(\gamma \mu_{g}-0.5 \gamma^{2} \sigma_{g}^{2}\right) t \\
& \rho=\delta+\gamma \mu_{g}-0.5 \gamma^{2} \sigma_{g}^{2}
\end{aligned}
$$

$\rho$ is the rate of return from social savings. In the margin, the SDR is equal to the rate of return from social savings $\rho$.

The discrete annual rate is equal to:

$$
r=e^{\rho}-1=e^{\delta+\gamma \mu_{g}-0.5 \gamma^{2} \sigma_{g}^{2}}-1
$$


If consumption decreases, $c_{i t}<c_{i 0}$, then

$$
W=\sum_{i} \lambda_{i}\left(u\left(c_{i 0}\right)+e^{-\delta t} E\left[u\left(f\left(c_{i t}\right)\right)\right]\right)
$$

In a context of efficient risk-sharing and:

$$
\begin{gathered}
\frac{\partial W}{\partial c}=0: \\
u^{\prime}\left(c_{0 t}\right)-e^{\rho-\delta} f^{\prime}\left(c_{i t}\right) E\left[u^{\prime}\left(c_{i t}\right)\right]=0
\end{gathered}
$$

where

$$
\begin{aligned}
& f^{\prime}\left(c_{i t}\right)=\frac{\partial f\left(c_{i t}\right)}{\partial c_{i t}}=2 \\
& e^{\rho-\delta}=u^{\prime}\left(c_{i 0}\right) / 2 E u^{\prime}\left(c_{i t}\right) \\
& \log e^{\rho-\delta}=\log \left(u^{\prime}\left(c_{i 0}\right) / 2 E u^{\prime}\left(c_{i t}\right)\right) \\
& \rho=\delta-\log \left(2 E u^{\prime}\left(c_{i t}\right) / u^{\prime}\left(c_{i 0}\right)\right)
\end{aligned}
$$

We also assume that if the growth rate of consumption $x_{i t}$ is normally distributed with mean $\mu_{g}$ and variance $\sigma_{g}^{2}$, then equation (54) can be rewritten as:

$$
\rho=\delta+2 \gamma \mu_{g}-\gamma^{2} \sigma_{g}^{2}
$$

And the discrete annual rate is equal to:

$$
r=e^{\rho}-1=e^{\delta+2 \gamma \mu_{g}-\gamma^{2} \sigma_{g}^{2}}-1
$$

In an entrepreneurial economy, according to Petrakis (2014), its rate of growth is dependent on the NSR of entrepreneurship with a factor of 0.25 . For the entrepreneur agent $i$, this factor indicates the project's dependence on NSRt, and an expectation of consumption rate of $\mu+0.25$ NSR because the return of the agent's savings can be higher than $\rho$. Then, we can rewrite equations (48) and (57) in the following ways:

$$
\begin{array}{llrl}
r=e^{\delta+\gamma\left(\mu_{g}+0.25 N S R\right)-0.5 \gamma^{2} \sigma_{g}^{2}}-1 & \text { if } \quad \mathrm{c}_{\mathrm{it}}>\mathrm{c}_{\mathrm{i} 0} \\
r=e^{\delta+2\left(\gamma(1+0.25 N S R) \mu_{g}-\gamma^{2} \sigma_{g}^{2}\right)}-1 & \text { if } \quad \mathrm{c}_{\mathrm{it}}<\mathrm{c}_{\mathrm{i} 0}
\end{array}
$$


These are the two branches, in discrete time, of the annual ESDR applied to cash flows.

\section{Numerical Example}

The following is a numerical example to show how to apply the ESDR to the valuation of new ventures. For simplicity, we assume that:

- The representative entrepreneurial agent has 100 monetary units (m.u.) each year for consumption with the possibility to invest other 100 m.u. in one of three alternative investment opportunities with a time horizon of 10 years for each.

- In all cases, the investments are financed with a mix of entrepreneurs' personal savings and government funds.

- There is no possibility to accumulate savings, and each cash flow is consumed in its corresponding period.

The three investment alternatives are the following:

Alternative A: To invest 100 m.u. in a safe investment with a return of 3.5 each year and with the possibility to recover the initial investment in the last year. Hence, the investment is completely reversible. The cash flows of this safe investment are shown in Table 1.

Table 1. Cash flows of alternative A

\begin{tabular}{|l|c|c|c|c|c|c|c|c|c|c|c|}
\hline Year & 0 & 1 & 2 & 3 & 4 & 5 & 6 & 7 & 8 & 9 & 10 \\
\hline $\begin{array}{l}\text { Expected } \\
\text { Cash flows }\end{array}$ & -100 & 3.5 & 3.5 & 3.5 & 3.5 & 3.5 & 3.5 & 3.5 & 3.5 & 3.5 & 103.5 \\
\hline
\end{tabular}

Alternative B: To invest 100 m.u. in a new venture with a probable loss of $50 \%$ and a probable gain of $50 \%$. The loss is a constant 10 m.u. per year, and the profit in the first year is 10 m.u. but increases by 10 m.u. each year. Cash flows for both alternatives are shown in Table 2 .

Table 2. Cash flows of alternative B

\begin{tabular}{|l|c|c|c|c|c|c|c|c|c|c|c|}
\hline Year & $\mathbf{0}$ & $\mathbf{1}$ & $\mathbf{2}$ & $\mathbf{3}$ & $\mathbf{4}$ & $\mathbf{5}$ & $\mathbf{6}$ & $\mathbf{7}$ & $\mathbf{8}$ & $\mathbf{9}$ & $\mathbf{1 0}$ \\
\cline { 1 - 11 } $\begin{array}{l}\text { Negative scenario } \\
\text { (Prob.50\%) }\end{array}$ & -100 & -10 & -10 & -10 & -10 & -10 & -10 & -10 & -10 & -10 & -10 \\
\cline { 1 - 10 } & $\begin{array}{l}\text { Positive scenario } \\
\text { (Prob.50\%) }\end{array}$ & 10 & 20 & 30 & 40 & 50 & 60 & 70 & 80 & 90 & 100 \\
\cline { 1 - 10 } $\begin{array}{l}\text { Expected cash- } \\
\text { flows }\end{array}$ & $\mathbf{- 1 0 0}$ & $\mathbf{0}$ & $\mathbf{5}$ & $\mathbf{1 0}$ & $\mathbf{1 5}$ & $\mathbf{2 0}$ & $\mathbf{2 5}$ & $\mathbf{3 0}$ & $\mathbf{3 5}$ & $\mathbf{4 0}$ & $\mathbf{4 5}$ \\
\hline
\end{tabular}

Alternative C: To invest 100 m.u. in a new venture that faces four scenarios (i.e., optimistic, realistic, business-as-usual, and pessimistic) equally probable (25\%). Cash flows for every scenario are shown in Table 3. 
Table 3. Cash flows of alternative $\mathrm{C}$

\begin{tabular}{|c|c|c|c|c|c|c|c|c|c|c|c|}
\hline Year & 0 & 1 & 2 & 3 & 4 & 5 & 6 & 7 & 8 & 9 & 10 \\
\hline $\begin{array}{l}\text { Optimistic scenario } \\
(25 \%)\end{array}$ & \multirow{4}{*}{-100} & 20 & 80 & 40 & 20 & 40 & 80 & 40 & 20 & 40 & 80 \\
\hline $\begin{array}{l}\text { Realistic scenario } \\
(25 \%)\end{array}$ & & 13 & 40 & 20 & 10 & 20 & 40 & 20 & 10 & 20 & 40 \\
\hline $\begin{array}{l}\text { Business-as- usual } \\
\text { scenario }(25 \%)\end{array}$ & & 10 & 20 & 10 & 5 & 10 & 20 & 10 & 5 & 10 & 20 \\
\hline $\begin{array}{l}\text { Pessimistic } \\
\text { scenario (25\%) }\end{array}$ & & -8 & -8 & -8 & -8 & -8 & -8 & -8 & -8 & -8 & -8 \\
\hline $\begin{array}{l}\text { Expected cash } \\
\text { flows }\end{array}$ & -100 & 8.7 & 33 & 15.5 & 6.75 & 15.5 & 33 & 15.5 & 6.75 & 15.5 & 33 \\
\hline
\end{tabular}

The internal return rates (IRR) of the expected cash flows for the three alternative investments (A, B and C) are the following: 3.5\%, 12.21\%, and 12.21\%, respectively. The NSR is estimated as the proportion of the total volatility of the new venture's returns (return on invested capital - ROIC) that is not explained by the lineal regression between the new ventures' systematic or market risk and economic growth (specific risk):

$$
N S R=\left(1-R^{2}\right) \sigma_{R O I C}
$$

If we consider the Petrakis' (2004) result of a positive correlation between non-systematic risk and the growth rate of consumption of about $25 \%$, hence $\left(1-R^{2}\right)=0.25$, then the investment's total risk can be estimated as the volatility of the ROIC. Then, the NSR value for alternatives B and C are: Alternative B: $3.78 \%$

Alternative C: $2.68 \%$

Tables 1, 2 and 3 show the cash flows for each alternative, so now we proceed to evaluate each investment alternative using the SDR and ESDR using only cash flows. We estimate the continuous annual SDR by considering the same standard assumptions in the literature (see Gollier, 2008, 2011; and Arrow et al., 2014):

- The annual growth rate of consumption is $1.8 \%$, and its volatility is $3.6 \%$.

- $\quad$ The rate of pure preference is $\delta=0$.

- The relative risk aversion is $\gamma=2$.

Under these assumptions, the values of the annual SDR are the following (using equations (19) and (21) that correspond to positive returns):

The annual continuous time rate is:

$$
S D R=0+2(1.8 \%)-(0.5)(2)^{2}(3,6 \%)^{2}=3.341 \% .
$$

The annual discrete time rate is:

$$
S D R=e^{3.341 \%}-1=3.397 \%
$$


We also use the previous assumptions to calculate the values of the annual ESDR in discrete time (using equations (23) and (24)):

ESDR $_{\text {AlternativeB: }}$

Positive returns according to equation (23) are:

$$
\begin{gathered}
\rho=0+2(1+0.25 \cdot 0.0378) \cdot 1,8 \%-(0.5)(2)^{2}(3,6 \%)^{2}=3.375 \% \quad \text { and } \\
r=e^{3,375 \%}-1=3.432 \% .
\end{gathered}
$$

If the representative investor suffers from loss aversion, then the discrete time, loss aversion discount rate will change over time. Therefore, we use equation (24) to obtain the following for the first year: $r_{\text {lossaversion }}=e^{3.375 \%} \cdot 2^{1 / 1}-1=106.86 \%$.

Now we must calculate the time-varying loss-aversion returns for every year and then estimate the present value of alternative B (see Table 4).

Table 4. Valuation of investment alternative B

\begin{tabular}{|c|c|c|c|c|c|c|c|c|c|c|}
\hline Year & $\mathbf{1}$ & $\mathbf{2}$ & $\mathbf{3}$ & $\mathbf{4}$ & $\mathbf{5}$ & $\mathbf{6}$ & $\mathbf{7}$ & $\mathbf{8}$ & $\mathbf{9}$ & $\mathbf{1 0}$ \\
\hline ESDR & $106.86 \%$ & $\begin{array}{c}46.28 \\
\%\end{array}$ & $\begin{array}{c}30.32 \\
\%\end{array}$ & $23 \%$ & $\begin{array}{c}18.81 \\
\%\end{array}$ & $\begin{array}{c}16.10 \\
\%\end{array}$ & $\begin{array}{c}14.20 \\
\%\end{array}$ & $\begin{array}{c}12.79 \\
\%\end{array}$ & $\begin{array}{c}11.71 \\
\%\end{array}$ & $\begin{array}{c}10.86 \\
\%\end{array}$ \\
\hline DF & 0.48 & 0.33 & 0.25 & 0.21 & 0.17 & 0.15 & 0.13 & 0.12 & 0.10 & 0.09 \\
\hline CF & 0 & 5 & 10 & 15 & 20 & 25 & 30 & 35 & 40 & 45 \\
\hline PV & $\mathbf{3 0 . 8 5}$ & & & & & & & & & \\
\hline
\end{tabular}

CF: Cash flows; ESDR: entrepreneurial social discount rate; DF: discount factor using forward discount rates; and PV: present value of the investment alternative.

Now, we evaluate the investment alternative $\mathrm{C}$ by first estimating the ESDR for this alternative:

ESDR Alternativec:

Positive returns according to equation (23) are:

$$
\begin{gathered}
\rho=0+2(1+0.25 \cdot 0.0268) \cdot 1,8 \%-(0.5)(2)^{2}(3,6 \%)^{2}=3.365 \% \text { and } \\
r=e^{3,365 \%}-1=3.422 \% \text { is the discrete time annual rate. }
\end{gathered}
$$

If the representative investor suffers from loss aversion, then the discrete time, loss aversion discount rate will change over time. Therefore, we use equation (24) to obtain the following for the first year: $r_{\text {lossaversion }}=e^{3.365 \%} \cdot 2^{1 / 1}-1=106.84 \%$.

Now we must calculate the time-varying loss-aversion returns for every year and then estimate the present value of alternative B (see Table 5). 
Table 5. Valuation of investment alternative $C$

\begin{tabular}{|c|c|c|c|c|c|c|c|c|c|c|}
\hline Year & $\mathbf{1}$ & $\mathbf{2}$ & $\mathbf{3}$ & $\mathbf{4}$ & $\mathbf{5}$ & $\mathbf{6}$ & $\mathbf{7}$ & $\mathbf{8}$ & $\mathbf{9}$ & $\mathbf{1 0}$ \\
\hline ESDR & $106.84 \%$ & $46.24 \%$ & $30.3 \%$ & $22.99 \%$ & $18.8 \%$ & $16.09 \%$ & $14.19 \%$ & $12.78 \%$ & $11.7 \%$ & $10.85 \%$ \\
\hline DF & 0.48 & 0.33 & 0.25 & 0.21 & 0.17 & 0.15 & 0.13 & 0.12 & 0.10 & 0.09 \\
\hline CF & 8.74 & 33 & 15.5 & 6.75 & 15.5 & 33 & 15.5 & 6.75 & 15.5 & 33 \\
\hline PV & $\mathbf{3 5 . 6 0}$ & & & & & & & & & \\
\hline
\end{tabular}

CF: cash flows; ESDR: entrepreneurial social discount rate; DF: discount factor using forward discount rates; and PV: present value of the investment alternative.

Table 6 has a comparison of the PV associated with each investment alternative by considering three situations: the risk-free rate, the SDR, and the ESDR.

If we use the IRR from the traditional financial analysis, then the alternatives $\mathrm{B}$ and $\mathrm{C}$ are equally desirable. If we use the SDR as the best option (higher expected present value), then alternative B (the first new venture) is better; but if we consider the risk premium due to NSR and the average representative entrepreneur's loss aversion, the best option is alternative $C$ (the second venture), which has less scenarios with losses.

Table 6. Comparison of NPV across the three perspectives: certainty, SDR, and ESDR (cash-flow approach)

\begin{tabular}{|l|c|c|c|}
\hline & Alternative A & Alternative B & Alternative C \\
\hline IRR & $3.5 \%$ & $\mathbf{1 2 . 2 1 \%}$ & $\mathbf{1 2 . 2 1 \%}$ \\
\hline $\begin{array}{l}\text { Net Present Value at rate 3.5\% free- } \\
\text { risk rate }\end{array}$ & 100.00 & $\mathbf{1 7 5 . 3 5}$ & 151.08 \\
\hline $\begin{array}{l}\text { Net Present Value at rate 3.397\% } \\
\text { SDR }\end{array}$ & 100.86 & $\mathbf{1 7 6 . 6 0}$ & 151.90 \\
\hline $\begin{array}{l}\text { Net Present Value at rate ESDR with } \\
\text { loss aversion }\end{array}$ & 30.85 & $\mathbf{3 5 . 6 0}$ \\
\hline
\end{tabular}

For the consumption scenario, we need to add up 100 m.u. of initial wealth to the cash flows reported in Tables 1, 2, and 3 (see Table 7). We use the same assumptions and equations (19) and (21), which correspond to positive returns, to obtain the same values for the SDR:

The annual continuous-time rate is:

$$
S D R=0+2 \cdot 1,8 \%-(0.5)(2)^{2}(3,6 \%)^{2}=3.341 \% .
$$

The annual discrete-time rate is:

$$
S D R=e^{3,341 \%}-1=3.397 \% .
$$

We also use the previous assumptions to calculate the values of the annual ESDR in discrete time, but in this case we use equations (59) and (60):

$\mathrm{ESDR}_{\text {alternativeB: }}$

If consumption is higher or equal to 100 , then

$$
\rho=0+2(1,8 \%+0.25 \cdot 0.0378)-(0.5)(2)^{2}(3,6 \%)^{2}=5.233 \%
$$


In the annual discrete rate ESDR: $r=e^{5.233 \%}-1=5.372 \%$.

If consumption is lower than 100 , then

$$
\rho=0+2 \cdot 2 \cdot 1,8 \%(1+0.25 \cdot 0.0378)-(2)^{2}(3,6 \%)^{2}=6.75 \%
$$

In the annual discrete rate: ESDR: $r=e^{6.75 \%}-1=6.983 \%$

Table 7. Consumption per alternative and year

\begin{tabular}{|c|c|c|c|c|c|c|c|c|c|c|c|}
\hline Year & $\mathbf{0}$ & 1 & 2 & 3 & 4 & 5 & 6 & 7 & 8 & 9 & 10 \\
\hline Alternative A & \multirow{10}{*}{100} & & & & & & & & & & \\
\hline $\begin{array}{l}\text { Safe investment } \\
\text { consumption }\end{array}$ & & 103.5 & 103.5 & 103.5 & 103.5 & 103.5 & 103.5 & 103.5 & 103.5 & 103.5 & 203.5 \\
\hline Alternative B & & & & & & & & & & & \\
\hline $\begin{array}{l}\text { Positive } \\
\text { scenario }\end{array}$ & & 110 & 120 & 130 & 140 & 150 & 160 & 170 & 180 & 190 & 200 \\
\hline $\begin{array}{l}\text { Negative } \\
\text { scenario }\end{array}$ & & 90 & 90 & 90 & 90 & 90 & 90 & 90 & 90 & 90 & 90 \\
\hline Alternative C & & & & & & & & & & & \\
\hline $\begin{array}{l}\text { Optimistic } \\
\text { scenario }\end{array}$ & & 120 & 180 & 140 & 120 & 140 & 180 & 140 & 120 & 140 & 180 \\
\hline $\begin{array}{l}\text { Realistic } \\
\text { scenario }\end{array}$ & & 112.95 & 140 & 120 & 110 & 120 & 140 & 120 & 110 & 120 & 140 \\
\hline $\begin{array}{l}\text { Business-as- } \\
\text { usual scenario }\end{array}$ & & 110 & 120 & 110 & 105 & 110 & 120 & 110 & 105 & 110 & 120 \\
\hline $\begin{array}{l}\text { Pessimistic } \\
\text { scenario }\end{array}$ & & 92 & 92 & 92 & 92 & 92 & 92 & 92 & 92 & 92 & 92 \\
\hline
\end{tabular}

ESDR $_{\text {alternativec: }}$

If consumption is higher or equal to 100 , then

$$
\rho=0+2(1,8 \%+0.25 \cdot 0.0268)-(0.5)(2)^{2}(3,6 \%)^{2}=4.683 \%
$$

In the annual discrete rate ESDR: $r=e^{4.683 \%}-1=4.794 \%$.

If consumption is lower than 100 , then

$$
\rho=0+2 \cdot 2 \cdot 1,8 \%(1+0.25 \cdot 0.0268)-(2)^{2}(3,6 \%)^{2}=6.730 \%
$$

In the annual discrete rate: ESDR: $r=e^{6.73 \%}-1=6.962 \%$.

Due to the fact that part of the cash flows depends on the investment alternatives, we must convert the discrete time rates $(6.983 \%$ and $6.962 \%)$ to the loss aversion, discrete time rate when consumption is lower than 100 . Hence, from equation (18) we get:

$$
r_{\text {lossaversion }}=(1+r) 2^{1 / t}-1
$$

ESDR $_{\text {alternativeB }}$ :

$r_{\text {lossaversion }}=(1+6.983 \%) 2^{1 / 1}-1=113.97 \%$ for the first year and then we calculate the remaining rates and the corresponding discount factors. Then we evaluate alternative B: 
Table 8. Valuation of investment alternative B

\begin{tabular}{|c|c|c|c|c|c|c|c|c|c|c|}
\hline Year & $\mathbf{1}$ & $\mathbf{2}$ & $\mathbf{3}$ & $\mathbf{4}$ & $\mathbf{5}$ & $\mathbf{6}$ & $\mathbf{7}$ & $\mathbf{8}$ & $\mathbf{9}$ & $\mathbf{1 0}$ \\
\hline ESDR & $113.97 \%$ & $51.30 \%$ & $34.79 \%$ & $27.22 \%$ & $22.89 \%$ & $20.08 \%$ & $18.12 \%$ & $16.67 \%$ & $15.55 \%$ & $14.66 \%$ \\
\hline DF & 0.47 & 0.31 & 0.23 & 0.18 & 0.15 & 0.12 & 0.10 & 0.09 & 0.08 & 0.07 \\
\hline CF & 100 & 105 & 110 & 115 & 120 & 125 & 130 & 135 & 140 & 145 \\
\hline PV & $\mathbf{2 0 3 . 7 6}$ & & & & & & & & & \\
\hline
\end{tabular}

CF: cash flows; ESDR: entrepreneurial social discount rate; DF: discount factor using forward discount rates; and PV: present value of the investment alternative.

We proceed in the same way with alternative C (see Table 9):

Table 9. Valuation of investment alternative $\mathrm{C}$

\begin{tabular}{|c|c|c|c|c|c|c|c|c|c|c|}
\hline Year & $\mathbf{1}$ & $\mathbf{2}$ & $\mathbf{3}$ & $\mathbf{4}$ & $\mathbf{5}$ & $\mathbf{6}$ & $\mathbf{7}$ & $\mathbf{8}$ & $\mathbf{9}$ & $\mathbf{1 0}$ \\
\hline ESDR & $113.92 \%$ & $51.27 \%$ & $34.76 \%$ & $27.20 \%$ & $22.87 \%$ & $20.06 \%$ & $18.10 \%$ & $16.64 \%$ & $15.52 \%$ & $14.64 \%$ \\
\hline DF & 0.47 & 0.31 & 0.23 & 0.18 & 0.15 & 0.12 & 0.10 & 0.09 & 0.08 & 0.07 \\
\hline CF & 108.74 & 133 & 115.5 & 106.75 & 115.5 & 133 & 115.5 & 106.75 & 115.5 & 133 \\
\hline PV & $\mathbf{2 1 0 . 0 7}$ & & & & & & & & & \\
\hline
\end{tabular}

CF: cash flows; ESDR: entrepreneurial social discount rate; DF: discount factor using forward discount rates; and PV: present value of the investment alternative.

Finally, Table 10 compares the PV associated with each investment alternative by considering three situations: the risk-free rate, the SDR, and the ESDR.

Table 10. Comparison of NPV across the three perspectives: certainty, SDR, and ESDR (Consumption approach)

\begin{tabular}{|l|c|c|c|}
\hline & Alternative A & Alternative B & Alternative C \\
\hline IRR & $3.5 \%$ & $104.66 \%$ & $\mathbf{1 1 5 . 8 9 \%}$ \\
\hline $\begin{array}{l}\text { Net Present Value at rate 3.5\% free- } \\
\text { risk rate }\end{array}$ & 931.66 & $\mathbf{1 , 0 0 7 . 0 1}$ & 982.75 \\
\hline $\begin{array}{l}\text { Net Present Value at rate 3.397\% } \\
\text { SDR }\end{array}$ & 936.86 & $\mathbf{1 , 0 1 2 . 6 0}$ & 987.90 \\
\hline $\begin{array}{l}\text { Net Present Value at rate ESDR with } \\
\text { loss aversion }\end{array}$ & & 203.76 & $\mathbf{2 1 0 . 0 7}$ \\
\hline
\end{tabular}

In this case, the IRR favors alternative $\mathrm{C}$, but the present values (PV) with the risk-free rate and with the SDR indicate that alternative B (the first venture) is the best one. However, if we consider the risk premium instead of the NSR and the representative entrepreneur's loss aversion, thenthe best option is alternative $C$ (the second venture), which has less scenarios with losses.

In brief, with the cash-flow approach (Table 6) and with the consumption approach (Table 10), the evaluation of the three alternatives yields alternative $C$ as the best option for using the ESDR because it has less scenarios with losses and lower variability. This option means the cognitive bias of loss aversion matters when evaluating projects from the societal point of view. In fact, the ESDR focuses on the most conservative case when the representative entrepreneur suffers from loss 
aversion and therefore they require high initial discount rates, but these rates decrease over time. To have high initial discount rates is consistent with avoiding overconfidence too.

In our estimations, we have assumed a correlation coefficient of $25 \%$ as in Petrakis (2004), and the suggestion provided by Book (1999) that a sensible value for the correlation coefficient must range between $20 \%$ and $30 \%$ when this value is not known. However, Smart (2013) obtains a robust estimation of the correlation coefficient of $63 \%$ that we must use whenever we do not know the correlation coefficient. In his words: "This approach is robust in the sense that without solid evidence to assign a correlation value, it minimizes the amount by which the total standard deviation is underestimated or overestimated due to the correlation assumption (Smart, 2013, 4)"

Table 11 shows the sensitivity analysis of our results with the two frameworks whenever we use a correlation coefficient of $25 \%$ or $63 \%$. We conclude that the change in the PVs is quite small; therefore, the decision does not change, and we have support for our initial estimate of $25 \%$.

Table 11. Sensitivity analysis of the NPV with respect to the correlation coefficient

\begin{tabular}{|c|c|c|c|}
\hline Approach & Alternative & $\begin{array}{c}\text { Correlation } \\
\text { coefficient }\end{array}$ & PV (ESDR) \\
\hline \multirow{4}{*}{ Cash-flow approach } & \multirow{2}{*}{ Alternative B: $1^{\text {st }}$ new venture } & NSR: $25 \%$ & 30.85 \\
\hline & & NSR: $63 \%$ & 30.74 \\
\hline & \multirow{2}{*}{ Alternative C: $2^{\text {nd }}$ new venture } & NSR: $25 \%$ & 35.60 \\
\hline & & NSR: $63 \%$ & 35.55 \\
\hline \multirow{4}{*}{ Consumption approach } & \multirow{2}{*}{ Alternative B: $1^{\text {st }}$ new venture } & NSR: $25 \%$ & 203.76 \\
\hline & & NSR: $63 \%$ & 202.90 \\
\hline & \multirow{2}{*}{ Alternative C: $2^{\text {nd }}$ new venture } & NSR: $25 \%$ & 210.07 \\
\hline & & NSR: $63 \%$ & 209.48 \\
\hline
\end{tabular}

\section{Conclusion}

Almodóvar-González et al. (2020) have shown that entrepreneurial activity promotes economic growth in developed economies and developing economies should encourage this type of specific economic growth. Hence, specific or non-generic entrepreneurship matters for economic growth in developing economies in the long run. What sort of ventures are a priority for these governments? They are those ventures with a private-public collaboration in research and development in key industries that fosters economic growth.

The traditional SDR approach lacks the entrepreneurial element, so society may choose alternatives that are not in the best interest of social well-being. Consistent with this idea, we have shown an extension of the SDR that involves the risk premium due to the new ventures' NSR and the representative entrepreneur's loss-aversion coefficient. We named this extension the ESDR and show that we need to consider these two factors in order to evaluate new ventures that are going to be financed partially with government funds.

The ESDR supposes that representative entrepreneurs will require a higher return whenever they face a higher NSR and suffer from loss aversion. Hence, they will bring back the cash flows nearer to the present at a higher discount factor. Also, the ESDR supposes that new ventures with more 
scenarios of losses will have a higher discount rate of decreasing future consumption (less weight on future consumption in the case of losses). Also, this extended approach supposes the discount rate varies over a period in a declining way and has similar relative results with consumption (total wealth each period) or with cash flows (net earnings/loss each period).

This new discount rate is a more holistic approach that considers social and entrepreneurial factors in the economic debate on the discount rate to valuate social investment projects. In fact, our example shows that not considering the investment-specific risk and the entrepreneurs' loss aversion could lead to the selection of the wrong ventures to support.

In brief, the ESDR can be useful for public agencies to find better complementarity between public and private partnerships for new ventures according to their degree of innovation and possible impact on key industries. Therefore, these ventures can contribute or have the potential to contribute more to the economic growth of the country.

Furthermore, our proposed ESDR is compatible with the declining discount rate (DDR) theory because in all cases, the ESDR converges to the minimum possible consumption growth rate in the long term.

It also incorporates the well-known fear of failure in new ventures (Caccioti at al., 2016 and Mongrut and Juarez, 2020) through the loss-aversion coefficient. Its application assumes a timevarying discount rate whenever there is loss aversion either using the consumption or cash flows. Despite these benefits, calculating the proper long-term values for the model parameters is still important, especially for the new venture's total risk. The determination of a robust formula of ESDR that depends on time with a declining form (DDR) will be an additional generalization of ESDR for intergenerational projects or investment projects with intergenerational effects.

\section{References}

[1] Almordovar-González, M., Fernández-Portillo, A., and Díaz-Casero, J.C. (2020) Entrepreneurial Activity and Economic Growth: A multi-country analysis, European Research on Management and Business Economics, 26(1), 9-17. DOI: https://doi.org/10.1016/j.iedeen.2019.12.004

[2] Armitage, S. (2017). Discount rates for long-term projects: the cost of capital and social discount rate compared. The European Journal of Finance, 23(1), 60-79. DOI: https://doi.org/10.1080/1351847X.2015.1029591

[3] Arrow, K., Cropper, M., Gollier, C., Groom, B., Heal, G., Newell, R., Nordhaus, W., Pindyck, R., Pizer, W., Portney, P., Sterner, R., Tol, R., and Weitzman, M. (2014) Should Governments Use a Declining Discount Rate in Project Analysis? Review of Environmental Economics and Policy 8(2), 145-163. DOI: https://doi.org/10.1093/reep/reu008

[4] Book S. (1999) Why Correlation Matters in Cost Estimating, Advanced Training Session, 32nd Annual DOD Cost Analysis Symposium, Williamsburg, VA

[5] Cacciotti, G., Hayton, J. C., Mitchell, J. R., and Giazitzoglu, A. (2016). A reconceptualization of fear of failure in entrepreneurship. Journal of Business Venturing, 31, 302-325. DOI: https://doi.org/10.1016/j.jbusvent.2016.02.002

[6] Cruz, S. and Muñoz, M.J. (2006) Social discount rate: a revision. Anales de estudios económicos y empresariales, XVI, 75-98. http://uvadoc.uva.es/handle/10324/19791 
[7] Cumming, D., Johan, S. and Zhang, Y. (2018) Public policy towards entrepreneurial finance: spillovers and the scale-up gap, Oxford Review of Economic Policy, 34(4), 652-675. https://doi.org/10.1093/oxrep/gry012

[8] Drummond, M., Sculpher, M., Torrance, G., O’Brien, J., and Stoddart, G., (2005) Methods for the Economic Evaluation of Health Care Programmes. New York: Oxford University Press.

[9] Frid, C. J. (2014) Acquiring financial resources to form new ventures: the impact of personal characteristics on organizational emergence, Journal of Small Business \& Entrepreneurship 27(3), 323-341. DOI: https://doi.org/10.1080/08276331.2015.1082895

[10] Ge, D., Mahoney, J.M., \& Mahoney, J. (2005). New Venture Valuation by Venture Capitalists: An Integrative Approach. Working Papers 05-0124, University of Illinois at Urbana-Champaign, College of Business. http://www.business.illinois.edu/Working_Papers/papers/05-0124.pdf

[11] Gollier, C. (2008) Discounting with Fat-Tailed Economic Growth, Journal of Risk and Uncertainty 37(2), 171-186. DOI: https://doi.org/10.1007/s11166-008-9050-0

[12] Gollier, C. (2011) On the underestimation of the precautionary effect in discounting, Geneva Risk and Insurance Review, 36, 95-111. DOI: https://doi.org/10.1057/grir.2011.6

[13] Gollier, C. (2013) Pricing the planet's future: the economics of discounting in an uncertain world. Princeton; Oxford: Princeton University Press, 296 pp., ISBN: 9780691148762 https://doi.org/10.23943/princeton/9780691148762.001.0001

[14] Kahneman, D. and Tversky, A. (1979) Prospect theory: an analysis of decision under risk, Econometrica 47(2), 263-291. DOI: https://doi.org/10.2307/1914185

[15] Leach, J.C. and Melicher, R.W. (2020) Entrepreneurial Finance, Cengage Learning. USA. Seventh edition, 752 pp., ISBN: 9780357442043

[16] Mongrut S. and N. Juarez (2018) Valuation of Start-ups: A Behavioral and Strategic Perspective, Mexican Journal of Economics and Finance, 13(3), 419-439. DOI: https://doi.org/10.21919/remef.v13i3.314

[17] Mongrut S. and N. Juarez (2020) Fear of failure: what drives it in Latin America? Mexican Journal of Economics and Finance, 15(2), 473-501. DOI: https://doi.org/10.21919/remef.v15i0.542

[18] Novemsky, N. and Kahneman, D. (2005) The boundaries of loss aversion, Journal of Marketing Research, 42(2), 119-128. DOI: https://doi.org/10.1509/jmkr.42.2.119.62292

[19] Nofsinger, J. (2017) The psychology of investing, Routledge, Sixth Edition, 232 pp., ISBN: 9781138714809. DOI: https://doi.org/10.4324/9781315230856

[20] Nordhaus, W. (2007) A Review of the Stern Review on the Economics of Climate Change. Journal of Economic Literature, 45 (3), 686-702. DOI: https://doi.org/10.1257/jel.45.3.686

[21] Price, C. (1988) Investment, reinvestment, and the social discount rate for forestry, Forest Ecology and Management 24, 293-310. DOI: https://doi.org/10.1016/0378-1127(88)90106-5

[22] Petrakis, P.E. (2004) Entrepreneurship and risk premium, Small Business Economics 23, 85-98. DOI: https://doi.org/10.1023/B:SBEJ.0000027563.66389.4c

[23] Rathje J. and Katila R. (2018) Outcomes from institutional interaction: Does government funding help firm innovation? Academy of Management Proceedings, 1, 44 pp. DOI: https://doi.org/10.5465/AMBPP.2018.14701

[24] Ramsey, F. P. (1928) A mathematical theory of saving, Economic Journal 38 (4): 543-49. : http://www.jstor.org/stable/2224098

[25] Rodríguez, A. M. (2019) Profitability in complex investments: errors of IRR and other anomalies, their solutions, International Journal of Economics, Finance and Management Sciences 7(3), 88-94. https://doi.org/10.11648/j.ijefm.20190703.12

[26] Smart C. (2013) Robust default correlation for cost risk analysis, Proceedings from the ICEAA Professional Development \& Training Workshop, New Orleans, LA, 23 pp. 
[27] Zhuang, J., Liang, Z., Lin, T. and De Guzman, F. (2007) Theory and Practice in the Choice of Social Discount Rate for Cost-Benefit Analysis: A Survey. ERD ECONOMICS AND RESEARCH DEPARTMENT Working Paper SERIES No. 94. Asian Development Bank. https://www.adb.org/sites/default/files/publication/28360/wp094.pdf

\section{Appendix: Relation between returns with loss aversion and without loss aversion in continuous and discrete time}

\section{Continuous-time relation:}

According to Kahneman and Tversky (1979):

"For most of us, the amount you could possibly win would need to be at least twice as large as the amount you could lose before you would accept the risk. This tendency reflects loss aversion, or the idea that losses generally have a much larger psychological impact than gains of the same size".

Hence, loss aversion is about the future possibilities and not about their equivalent present values. We define:

$C F^{+}=$Positive cash flow from investment alternative A

$C F^{-}=$Negative cash flow from investment alternative $\mathrm{A}$

$\rho=$ Continuous-time required return without loss aversion

$\rho^{*}=$ Continuous-time required return with loss aversion

If we consider that the average coefficient of loss aversion is 2 , then we can define the following equivalence between the two continuous-time required returns in period " $t$ " in the future (when we will know the result):

$$
2\left(C F^{+}\right)\left(e^{\rho t}\right)=\operatorname{abs}\left(C F^{-}\right)\left(e^{\rho^{*} t}\right)
$$

Note that we must consider the absolute value of the negative cash flows because we only care about the same sized gains and losses.

Now we establish a relation between the two continuous-time required returns:

$$
\text { (2) }\left(e^{\rho t}\right)=\left(e^{\rho^{*} t}\right)
$$

Taking natural logarithms to both sides:

$$
\begin{gathered}
L N(2)+L N\left(e^{\rho t}\right)=L N\left(e^{\rho^{*} t}\right) \\
L N(2)+\rho t=\rho^{*} t
\end{gathered}
$$

Finally:

$$
\rho^{*}=\rho+L N(2)^{1 / t}
$$


Note that equation $(2 \mathrm{~A})$ indicates that the continuous-time required return demanded by an individual who suffers from loss aversion is positive and higher in the near future than in the distant future, and it will decrease over time.

\section{Discrete-time relation}

We start with the general definition between a continuous-time rate and the discrete-time rate using equivalent rates (note that it is also being established in future value terms):

$$
\left(1+\frac{r_{s}}{m}\right)^{(m)(t)}=(1+r)^{t}
$$

Where:

$r_{s}=$ Nominal discrete-time required return associated with simple interest

$r=$ Effective discrete-time required return associated with compound interest

$m=$ Capitalization period of the nominal required return

$t=$ Time period of the investment

The crucial question is: what would be the value of the nominal required return when the capitalization period is infinite? In this case we place limits on both sides of equation $(2 \mathrm{~A})$ :

$$
\begin{gathered}
\lim _{m \rightarrow \infty}\left(1+\frac{r_{s}}{m}\right)^{(m)(t)}=\lim _{m \rightarrow \infty}(1+r)^{t} \\
\lim _{m \rightarrow \infty}\left[\left(1+\frac{r_{s}}{m}\right)^{\frac{m}{r_{s}}}\right]^{\frac{r_{s}}{m}(m)(t)}=\lim _{m \rightarrow \infty}(1+r)^{t} \\
e^{(\rho)(t)}=(1+r)^{t}
\end{gathered}
$$

Further, when the capitalization period goes up to infinite, the discrete-time required return $\left(r_{s}\right)$ turns into a continuous-time required return $(\rho)$. Finally, placing natural logarithms in both sides of the equation, we obtain the relation:

$$
L N(1+r)=\rho
$$

Now we establish a relation between the discrete-time required returns with and without loss aversion:

$r=$ Discrete-time required return without loss aversion

$r^{*}=$ Discrete-time required return with loss aversion

Using equation $(2 \mathrm{~A})$ :

$$
\rho^{*}=\rho+L N(2)^{1 / t}
$$


We define the equation in terms of equation $(4 \mathrm{~A})$ :

$$
\begin{gathered}
L N\left(1+r^{*}\right)=L N(1+r)+L N(2)^{\frac{1}{t}} \\
L N\left(1+r^{*}\right)-L N(2)^{\frac{1}{t}}=L N(1+r) \\
L N\left(\frac{1+r^{*}}{(2)^{\frac{1}{t}}}\right)=L N(1+r)
\end{gathered}
$$

Placing an anti-natural logarithm in both sides, we obtain:

$$
\left(1+r^{*}\right)=(1+r)(2)^{\frac{1}{t}}
$$

We can use equation (5A) to calculate the equivalent rates in discrete time with and without loss aversion. Further, we can also establish a relation between the discrete-time rate with loss aversion and its corresponding continuous-time rate. Defining the logarithm and solving for the discrete-time rate in equation $(4 \mathrm{~A})$, we obtain:

$$
r=e^{\rho}-1
$$

Now we solve equation (5A) for the discrete-time required return with loss aversion:

$$
r^{*}=(1+r)(2)^{\frac{1}{t}}-1
$$

We plug equation (6A) into the previous one and get:

$$
r^{*}=\left(e^{\rho^{*}}\right)(2)^{\frac{1}{t}}-1
$$

Equation (7A) helps us calculate the discrete-time required return with loss aversion when using its corresponding continuous-time version. 